\title{
UPAYA PENINGKATAN KESEHATAN PADA IBU WARGA SENIOR MELALUI YOGA DI PUSAT PELAYANAN KELUARGA SEJAHTERA KELURAHAN KEJAKSAN KOTA CIREBON 2018
}

\author{
Nurasih Nurasih $^{1 *}$, Lia Nurcahyani ${ }^{1}$, Rani Widiyanti ${ }^{1}$ \\ ${ }^{1}$ Prodi Kebidanan Cirebon, Poltekkes Kemenkes Tasikmalaya, Indonesia \\ *Email: nurasih1610@yahoo.co.id
}

\begin{abstract}
Sign of the process Aging generally starts to appear at the age of 45 years and will cause problems at around 60 years of age. Yoga exercises include alternative forms of physical activity that can help in achieving the recommended level of physical exercise. Yoga Gymnastics is a holistic intervention that combines body posture (asanas), breathing (pranayama), and meditation. This Community Service activity aims to improve the health of elderly people through yoga. Community Service is carried out on 10 elderly women Prosperous Family Service Center Kejaksan Village, Kejaksan District, Cirebon City for three meetings. Activities carried out included Yoga exercises, blood pressure measurements and measurement of Distress scale for elderly women. The results of the activities obtained by mothers can do Yoga exercises according to the guidelines / instructions given in accordance with their respective body abilities, Elderly Yoga can reduce physical complaints felt by the elderly, the majority of Distress Scale shows relatively calm results after elderly Yoga, Pressure Systole and diastole blood are the same majority after or before doing Yoga. It is expected that Elderly Yoga Gymnastics can be practiced independently at home as an effort to improve the health of the Elderly and be used as a routine activity in The Center.
\end{abstract}

Keywords: Elderly, Yoga Gymnastics, Elderly Yoga.

\begin{abstract}
ABSTRAK
Tanda proses menua pada umumnya mulai tampak pada usia 45 tahun dan akan menimbulkan masalah pada usia sekitar 60 tahun. Senam Yoga termasuk alternative bentuk aktifitas fisik yang dapat membantu dalam mencapai tingkat latihan fisik yang disarankan. Senam Yoga merupakan intervensi holistik yang menggabungkan postur tubuh (asanas), pernafasan (pranayama), dan meditasi. Kegiatan Pengabdian pada Masyarakat ini bertujuan untuk meningkatkan kesehatan warga Lanjut Usia (Lansia) melalui Yoga. Pengabdian pada Masyarakat ini dilakukan pada 10 orang ibu-ibu Lansia di Pusat Pelayanan Keluarga Sejahtera (PPKS) Kelurahan Kejaksan Kecamatan Kejaksan Kota Cirebon selama tiga kali pertemuan. Kegiatan yang dilakukan meliputi senam Yoga, pengukuran tekanan darah dan pengukuran skala Distress terhadap ibu- ibu Lansia. Hasil kegiatan diperoleh ibu-ibu dapat melakukan senam Yoga sesuai dengan panduan/instruksi yang diberikan sesuai dengan kemampuan tubuh masing-masing, Yoga Lansia dapat mengurangi keluhan fisik yang dirasakan oleh warga Lansia, Mayoritas Skala Distress menunjukkan hasil relatif tenang setelah dilakukan Yoga Lansia, Tekanan Darah Sistole maupun diastole mayoritas sama sesudah maupun sebelum melakukan Yoga. Diharapkan Senam Yoga Lansia dapat dipraktikkan secara mandiri di rumah sebagai upaya meningkatkan kesehatan para Lansia dan dijadikan sebagai kegiatan rutin di PPKS.
\end{abstract}

Kata Kunci : Lansia, Senam Yoga, Yoga Lansia 


\section{PENDAHULUAN}

Proses penuaan merupakan suatu proses alami yang tidak dapat dicegah dan merupakan hal yang wajar dialami oleh orang yang diberi karunia umur panjang, dimana semua orang berharap akan menjalani hidup dengan tenang, damai, serta menikmati masa pensiun bersama anak dan cucu tercinta dengan penuh kasih sayang ${ }^{(2)}$.

Populasi jumlah warga senior (Lansia) di dunia mengalami peningkatan yang begitu pesat sebagai dampak dari perkembangan dan kemajuan ilmu pengetahuan serta teknologi. kemajuan di berbagai bidang teknologi khususnya dalam hal ini bidang kedokteran dan pengolahan pangan yang berkualitas. Hal itu mengakibatkan perubahan pola penyakit dari penyakit infeksi beralih ke penyakit degeneratif dan kardiovaskuler diantaranya adalah hipertensi

Lansia adalah tahap lanjut dari suatu siklus dan proses kehidupan yang ditandai dengan penurunan kemampuan tubuh untuk beradaptasi dengan stres lingkungan. Menurut UU RI No 13 tahun 1998 yang dimaksud dengan lanjut usia adalah seseorang yang telah mencapai usia 60 tahun keatas ${ }^{(3)}$. Berdasarkan data WHO (2000) diperkirakan terdapat 600 juta jiwa Lansia (usia lebih dari 60 tahun) di dunia. Angka tersebut akan mencapai 2 miliar orang pada tahun 2050. Distribusi populasi Lansia saat ini mengutip dari data yang dirilis PBB pada tahun 2006 sebanyak 65\%, dan tinggal di daerah negara berkembang serta diperkirakan akan meningkat mencapai kira-kira $75 \%$ pada tahun 2025 (4).

Indonesia merupakan salah satu negara berkembang yang mengalami peningkatan penduduk untuk lanjut usia. Badan Kependudukan dan Keluarga Berencana Nasional (BKKBN) menggagas pembentukan wadah yang dapat memberikan pelayanan/bantuan dalam bentuk konseling kepada keluarga yang dinamakan Pusat Pelayanan Keluarga Sejahtera (PPKS). Saat ini pelayanan yang diberikan di PPKS salah satunya termasuk menjangkau pada kelompok lanjut usia namun hanya sebatas pemberian konseling dan pemeriksaan kesehatan, sedangkan untuk upaya latihan fisik ringan dalam upaya meningkatkan kesehatan bagi Lansia belum dilakukan.

Meningkatnya jumlah populasi Lansia serta sudah ada kegiatan kelompok Lansia namun belum menjangkau pada peningkatan kesehatan secara fisik, mengakibatkan dirasakan perlu untuk mengadakan pelayanan dalam bentuk latihan fisik kepada warga Lansia melalui Yoga.

\section{METODE PELAKSANAAN}

Kegiatan Pengabdian kepada Masyarakat ini diawali dengan melakukan analisis situasi yang terjadi di lapangan (PPKS), dan studi literatur terkait dengan pelaksanaan senam Yoga untuk Lansia. Selanjutnya melakukan proses perizinan pelaksanaan Pengabdian pada Masyarakat di PPKS setelah surat izin Pengabdian pada Masyarakat dari Poltekkes Kemenkes Tasikmalaya selesai dibuat. Setelah proses perizinan telah selesai selanjutnya tim melakukan pertemuan dengan Pengurus PPKS untuk membahas pelaksanaan Pengabdian pada Masyarakat yang akan dilakukan termasuk jadwal pertemuan kegiatan untuk mengkondisikan kesiapan tempat dan ibu-ibu Lansia yang akan dilibatkan. Tim Pengabdian pada Masyarakat selanjutnya mempersiapkan kebutuhan yang diperlukan dalam kegiatan tersebut, diantaranya : penyediaan konsumsi kegiatan, form (daftar hadir, pencatatan hasil pengukuran tekanan darah, dan skala distress), peralatan Yoga (matras, belt), panduan Yoga Lansia yang dipersiapkan untuk memandu ibu Lansia dalam melakukan Yoga baik di PPKS maupun untk latihan di rumah.

Sasaran kegiatan Pengabdian pada Masyarakat ini adalah Kelompok Ibu-ibu pengajian mingguan di PPKS wilayah Kelurahan Kejaksan Kota Cirebon sebanyak 10 orang dengan pertemuan 1 kali setiap minggunya dilakukan selama 3 minggu. Kegiatan senam Yoga dilakukan dengan instruktur dari tim Pengabdian pada Masyarakat yang sudah tersertifikasi teacher training Yoga Lansia, selanjutnya diikuti oleh ibu-ibu Lansia dibantu dengan panduan Yoga Lansia yang telah dibuat. Disamping itu pula untuk Lansia 
yang dinilai telah mampu dapat diberikan kesempatan untuk memberikan contoh pada sesama Lansia lainnya. Dalam pelaksanaan Yoga Lansia dilakukan pula pengukuran skala Distress dan pengukuran Tekanan Darah yang dilakukan sebelum dan setelah beryoga.

\section{HASIL DAN PEMBAHASAN}

Kegiatan Pengabdian pada Masyarakat ini telah dilakukan selama tiga kali pertemuan pada tanggal 03, 10, dan 16 Agustus 2018 yang dihadiri oleh Lansia sebanyak 10 orang dengan rentang usia (50 - 70 tahun), pengurus PPKS, dan Tim Pengabdian pada Masyarakat dengan melibatkan juga Mahasiswa.

Tabel 1. Distribusi Frekuensi skala Distress Sebelum dan Setelah Yoga Pada Lansia di PPKS Kelurahan Kejaksan Kota Cirebon

\begin{tabular}{cccc}
\hline No & Skala & $\mathbf{N}$ & $\mathbf{\%}$ \\
\hline 1. & $0-10$ & 1 & $10 \%$ \\
2. & $11-20$ & 4 & $40 \%$ \\
3. & $21-30$ & 4 & $40 \%$ \\
4. & $31-90$ & 1 & $10 \%$ \\
\hline & Total & $\mathbf{1 0}$ & $\mathbf{1 0 0 \%}$ \\
\hline No & Skala & $\mathbf{N}$ & $\mathbf{\%}$ \\
\hline 1. & $0-10$ & 2 & $20 \%$ \\
2. & $11-20$ & 7 & $70 \%$ \\
3. & $21-30$ & 0 & 0 \\
& & & $\%$ \\
4. & $31-90$ & 1 & $10 \%$ \\
\hline & Total & $\mathbf{1 0}$ & $\mathbf{1 0 0 \%}$
\end{tabular}

Tabel 2. Distribusi Frekuensi Tekanan Darah Sistole Pertemuan Ke I, II dan III sebelum dan setelah Yoga Pada Lansia di PPKS Kelurahan Kejaksan Kota Cirebon

\begin{tabular}{cccc}
\hline No & Tekanan Darah Sistole & N & \% \\
\hline 1. & Sistole sesudah $<$ sistole awal & 0 & $0 \%$ \\
2. & Sistole sesudah $>$ sistole awal & 3 & $30 \%$ \\
3. & Sistole sesudah $=$ sistole awal & 7 & $70 \%$ \\
\hline & Total & $\mathbf{1 0}$ & $\mathbf{1 0 0 \%}$ \\
\hline No & Tekanan Darah Sistole & $\mathbf{N}$ & $\mathbf{\%}$ \\
\hline 1. & Sistole sesudah $<$ sistole awal & 6 & 60 \\
2. & Sistole sesudah $>$ sistole awal & 3 & 30 \\
3. & Sistole sesudah $=$ sistole awal & 1 & 10 \\
\hline & Total & $\mathbf{1 0}$ & $\mathbf{1 0 0 \%}$ \\
\hline No & Tekanan Darah Sistole & $\mathbf{N}$ & $\mathbf{\%}$ \\
\hline 1. & Sistole sesudah $<$ sistole awal & 0 & $0 \%$ \\
2. & Sistole sesudah $>$ sistole awal & 2 & $20 \%$ \\
3. & Sistole sesudah $=$ sistole awal & 8 & $80 \%$ \\
\hline & Total & $\mathbf{1 0}$ & $\mathbf{1 0 0 \%}$ \\
\hline
\end{tabular}


Tabel 3. Distribusi Frekuensi Tekanan Darah Diastole Pertemuan Ke II, II dan III sebelum dan setelah Yoga Pada Lansia di PPKS Kelurahan Kejaksan Kota Cirebon

\begin{tabular}{|c|c|c|c|}
\hline No & Tekanan Darah Diastole & $\mathbf{N}$ & $\%$ \\
\hline 1. & Diastole sesudah $<$ Diastole awal & 0 & $0 \%$ \\
\hline 2. & Diastole sesudah $>$ Diastole awal & 0 & $0 \%$ \\
\hline \multirow[t]{2}{*}{3.} & Diastole sesudah $=$ Diastole awal & 10 & $100 \%$ \\
\hline & Total & 10 & $100 \%$ \\
\hline No & Tekanan Darah Diastole & $\mathbf{N}$ & $\%$ \\
\hline 1. & Diastole sesudah $<$ Diastole awal & 0 & $0 \%$ \\
\hline 2. & Diastole sesudah $>$ Diastole awal & 5 & $50 \%$ \\
\hline \multirow[t]{2}{*}{3.} & Diastole sesudah $=$ Diastole awal & 5 & $50 \%$ \\
\hline & Total & 10 & $100 \%$ \\
\hline No & Tekanan Darah Diastole & $\mathrm{N}$ & $\%$ \\
\hline 1. & Diastole sesudah $<$ Diastole awal & 1 & $10 \%$ \\
\hline 2. & Diastole sesudah $>$ Diastole awal & 1 & $10 \%$ \\
\hline \multirow[t]{2}{*}{3.} & Diastole sesudah $=$ Diastole awal & 8 & $80 \%$ \\
\hline & Total & 10 & $100 \%$ \\
\hline
\end{tabular}

Pengukuran skala distress sebelum Yoga diperoleh hasil dengan kategori relatif tenang dan cenderung stress masing-masing sebesar (40\%). Sedangkan pengukuran skala distress pada pertemuan terakhir menunjukkan hasil bahwa sebagian besar dengan kategori relatif tenang $(70 \%)$. Jika dibandingkan dengan sebelum Yoga, meskipun pada kedua pengukuran diperoleh hasil terdapat lansia dengan kategori kemungkinan Ditress, namun terdapat penurunan sebelum Yoga (nilai 41) setelah Yoga mengalami penurunan (nilai 32). Berdasarkan hasil wawancara yang telah dilakukan dengan Lansiadidapatkan informasi bahwa setelah mengikuti kegiatan senam Yoga dirasakan membawa manfaat Karena dari beberapa Lansia yang sedang merasakan keluhan seperti sakit pinggang, punggung menjadi berkurang serta merasakan pula menjadi lebih tenang dan mudah tidur, hal ini dimungkinkan karena senam Yoga dapat menstimulasi pengeluaran hormon endorphin. Endorphin adalah neuropeptide yang dihasilkan oleh tubuh pada saat kondisi tubuh dalam kaeadaan rileks. Endorphin dihasilkan di otak dan susunan syaraf tulang belakang. Hormon ini dapat berfungsi sebagai obat penenang alami yang diproduksi otak yang menghasilkan rasa nyaman, dan untuk mengurangi tekanan darah tinggi ${ }^{(5)}$. Menurut Sindhu Olaraga terbukti dapat meningkatkan kadar endorphin empat sampai lima kali di dalam darah. Sehingga semakin banyak melakukan latihan maka akan semakin tinggi pula kadar endorphin. Ketika seseorang melakukan latihan, maka endorphin akankeluar dan ditangkap oleh reseptor didalam hipotalamus dan sistem limbic yang berfungsi untuk mengatur emosi. Peningkatan endorphin terbukti berhubungan erat dengan penurunan rasa nyeri, peningkatan daya ingat, memperbaiki nafsu makan, kemampuan seksual, tekanan darah dan pernafasan ${ }^{(6)}$.

Pengukuran tekanan darah terhadap 10 Lansia dilakukan selama tiga kali pertemuan setiap sebelum dan setelah senam Yoga diperoleh informasi bahwa mayoritas dalam tekanan darah yang normal. Tekanan darah merupakan kekuatan lateral pada dinding arteri oleh darah yang didorong dengan tekanan dari jantung. Menurut Perry \& Potter (2005) tekanan darah dalam sistem arteri tubuh adalah indikator yang baik tentang kesehatan kardiovaskuler ${ }^{(7)}$. Hasil pengukuran tekanan didapatkan bahwa mayoritas Lansia dengan tekanan darah yang cenderung stabil baik tekanan sistole maupun diastole jika dibandingkan antara sesudah dengan sebelum melakukan Yoga. Sesuai yang disampaikan oleh Rahima dalam penelitiannya bahwa ada pengaruh yang signifikan antara senam Yoga dengan penurunan tekanan pada Lansia penderita Hipertensi. Dikatakan pula bahwa senam Yoga yang dilakukan secara teratur selama 12 minggu membuktikn hasil yang signifikan dapat mengurangi tekanan darah pada Lansia. Tekanan 
darah Lansia hasil Pengabdian pada Masyarakat ini menunjukkan hasil yang cenderung sama dimungkinkan karena kegiatan senam yoga yang dilakukan hanya dalam waktu 3 minggu dengan jadwal satu kali perminggunya, dan dari 10 Lansia yang mengikuti senam Yoga hanya satu yang menderita hipertensi itupun dengan hasil yang cenderung stabil tekanan sistole maupun diastolenya ${ }^{(1)}$.

\section{SIMPULAN}

Berdasarkan hasil kegiatan yang telah dilakukan maka dapat disimpulkan bahwa Yoga Lansia dapat mengurangi keluhan fisik yang dirasakan oleh warga Lansia, Mayoritas Skala Distress menunjukkan hasil relatif tenang setelah dilakukan Yoga Lansi, serta Tekanan Darah Sistole maupun diastole mayoritas sama sesudah maupun sebelum melakukan Yoga.

\section{DAFTAR PUSTAKA}

1. Rahima R. Adaptasi Faal Tubuh Terhadap Latihan Hatha Yoga Pada Lansia Penderita Hipertensi. 2017;17(2):169-77.

2. Romah Nur Ika. Kualitas Hidup Lansia. J Keperwatan, ISSN 2086-3071. 2012;120-32.

3. Infodatin PD dan IKR. Situasi dan Analisis Lanjut Usia. Jakarta; 2014.

4. Nirvikalpa Yoga Indonesia. Manual Book Yoga For Senior Teacher Training. Bandung; 2017.

5. Dinata W. Menurunkan Tekanan Darah Pada Lansia Melalui Senam Yoga. 2015;11.

6. Ovianasari A. Pengaruh Latihan Yoga Terhadap Tekanan Darah Pada Lansia Penderita Hipertensi di Dusun Niten Nogotirto Gamping Sleman Yogyakarta. 2015;

7. Prawesti D. Pengaruh Terapi Yoga Terhadap Penurunan Tekanan Darah pada Lansia dengan Hipertensi. STIKES RS. Baptis Kediri; 2015. 